\title{
ANTHROPOMETRICAL CHARACTERISTICS AND SOMATOTYPE OF YOUNG MACEDONIAN SOCCER PLAYERS AGED11-18
}

\author{
Zikica Tasevski, Nebojsa Markovski, Serjoza Gontarev \\ Ss. Cyril and Methodius University
}

\begin{abstract}
:
The success of a sports play is closely connected to the physical state of the athletes. In the evaluation of the physical status, aside from the physiological and fitness parameters, the anthopometric parameters have a significant influence. The aim of the study is to evaluate the changes of the anthropometric characteristics and somatotype components of young soccer players aged between 11 and 18.

The introduction discusses some assumptions and expectations. The measurements of 486 young soccer players who play in the teams of the First State League, with an average age of $15.8 \pm 1.4$, have been analyzed.

The methodology includes the sample having their height, weight, BMI index, diameter, size and skin folds measured, as well as their body composition and somatotype. The results schow that the 14-year-old boys were shorter and had weighed less than the rest of the age groups. The 16-year-olds and older ones had no differences in the measurements, which means that the participants slowly grow into what the older soccer players look like. All of the skin folds of the young Macedonian soccer players (except for the skin folds of the scapula) lessen as the players grow older. Another point that is discussed is the mesomorphic component that is dominant for the young players of every age group.

It can be concluded that the results can be used as a model for comparison of the anthropometric and somatotype data of the young players on a similar level in different countries.

The discussion can serve as normative anthropometric markers for regular sports medical check-ups of the young soccer players in our country.
\end{abstract}

Key words: soccer, performance, measures, growth, age

\section{Introduction}

Soccerhas been the most popular sport in the world for more than twelve years, regardless of whether it is viewed from the aspect of the number of spectators or from the number of active sports players. During that whole period, soccerhas been continuously developing, especially in the direction of increasing the physical demands and loads which soccer players are exposed to during the training sessions or matches. In contemporary soccer, there is a faster game, shorter time for reaction, less thinking, and more demands placed, combined with highly developed cognitive, functional, and of course, motor skills (Marković, Bradić, 2008).

Anthropometry is widely used in many scientific disciplines, such as ergonomics andhealth-related sciences. Due to its practical use, anthropometry is also used for understanding the physical characteristics (performances) of sports people in the field of sports science, which targets the improvement of one's athletic performance (Meszaros et al., 2000).
The assumption that anthropometrical characteristics affect the physical performance of soccer players has been proven in many types of research(Bell, Rhodes, 1975). The reported results provide evidence for sports officials (coaches, managers) as well as for soccer players about the importance of anthropometry (ACSM, 2009).

It is expected from the soccer players to possess certain morphological and physiological attributes in order to be continuously successful in their career. A significant correlation among the body mass, muscle mass, and work-rate profile has been established(Rienzi et al., 2000). Conducted research among young soccer players shows that age and physical characteristics are important indicators for identifying talented players andselecting them for a game (Gil et al., 2007).Besides the recognition of the importance of anthropometrical parameters in the process of selection and training of the soccer players, there are deficiencies regarding the precise and accurately published informa- 
tion about the anthropometrical characteristics of athletes, especially young soccer players in the national league of our country. There is also a lack of comparative studies of anthropometrical characteristics, body composition and somatotypes between the Macedonian athletes and the athletes of other countries.

The aim of this paper is to determine the differences in some anthropometrical characteristics and somatotype components among the young soccer players between the ages of 11 and 18 . The results from this research can provide useful information for sport experts in order to create a successful training model for their soccer players and to identify young talented players.

\section{Methods}

Subjects:

The sample consists of 486 young soccer players, who play in the best clubs in the Macedonian first league, between the ages of 14 and 18, with an average age of $15.8 \pm 1$.4years. The sample is divided into five different age groups: 14years $(\mathrm{n}=111) ; 15$ years $(\mathrm{n}=111) ; 16$ years $(\mathrm{n}=100) ; 17$ years $(\mathrm{n}=88)$; 18 years $(n=78)$. This study includes all the soccer players whose parents have agreed to participate in the research. The respondents were treated in accordance with the Helsinki Declaration.

\section{Protocols and equipment:}

All the measurements were carried out by senior experts, trainers and experienced technicians. Height and body weight was measured using a ste- mometer (Seca, Leicester, UK) and electronic scales (HD-351, Tanita, Illinois, USA). The cutters were measured with auxiliary John Bull calipers. The volumes were measured with standard elastic mercury tape, as long as the diameters use a hexagonal hexagon (GPMc).Apart from height and weight, the following anthropometric measures were measured for calculating the somatotype components: biceps girth, calf girth, femoris breadth, humeral breadth, triceps skinfold, subscapular skinfold, supraspinale skinfold, and calf skinfold. Somatotype components (endomorphy-mesomorphy-ectomorphy) were calculated in accordance withthe Carter and Heath method (1990), using the somatotype software (SomatotypeV.1_2_5).

\section{Statistical methods:}

The data were analyzed using the Statistical Package for Social Sciences software (SPSS, v. 22.0 for WINDOWS; SPSS Inc., Chicago, IL, USA), and values of $\mathrm{p}<0.05$ were considered statisticallysignificant.Individual age groups were evaluated using a one-way analysis of the variance (ANOVA). Scheffés test was used as a post-hoc test when equal variances were assumed and the Games-Howell test when equal variances could not be assumed.

\section{Results}

The 14-year-old players are shorter and have lower body weight in comparison to other age groups ( $\mathrm{p}<0.001)$. Their BMI index is also the lowest (Table $1)$. The weight of the 15 -year-old players is lower in comparison to other players at the age of 17 and 18 $(p<0.05)$ and their BMI index is significantly statistically lower than the players aged $18(\mathrm{p}<0.01)$.

Table 1. Weight $(\mathrm{kg})$, height $(\mathrm{cm})$ and BMI. The values are shown as the mean \pm standard deviation.

\begin{tabular}{llllll}
\hline \multicolumn{5}{l}{ Age group (years) } & \multicolumn{5}{l}{} \\
\hline & 14 & 15 & 16 & 17 & 18 \\
\cline { 2 - 6 } Soccerplayers & & & & & \\
\hline Height & $170,648,05 \pm^{\mathrm{a}}$ & $174,986,14 \pm^{\mathrm{b}}$ & $176,386,77 \pm$ & $175,996,74 \pm$ & $177,086,46 \pm^{*}$ \\
Weight & $60,0510,89 \pm^{\mathrm{a}}$ & $65,538,16 \pm^{\mathrm{b}}$ & $68,707,51 \pm$ & $69,657,78 \pm$ & $70,087,46 \pm^{*}$ \\
BMI & $20,133,69 \pm^{\mathrm{a} *}$ & $21,372,12 \pm^{\mathrm{c}}$ & $21,852,92 \pm$ & $22,182,92 \pm$ & $22,311,66 \pm^{*}$ \\
\hline
\end{tabular}

Differences between soccerplayers $^{\mathrm{a}}-14$ years vs. $15,16,17$ and 18 -year-old groups, $\mathrm{p}<0.00$; $^{\mathrm{b}}-15$ years vs. 17 and 18 years, $\mathrm{p}<0.05 ;^{\mathrm{c}}-15$ years vs. 18 years, $\mathrm{p}<0.01$.

Table 2 shows the average values of ectomorphy, mesomorphy and endomorphy components. In all of the age groups, the mesomorphy component of the somatotype is dominant. Among the youngest players the average values of the ectomorphy component are statistically and significantly higher in comparison to the players of all the other age groups $(\mathrm{p}<0.05)$. Players at the age of 15 have statistically and sigificantly higher values of the ectomorphy components in comparison to players at the age of 17 ( $\mathrm{p}<0.05)$. 
Table 2. Scores (mean \pm standard deviation) of the three components of the somatotype of soccer players by age

\begin{tabular}{|c|c|c|c|c|c|}
\hline \multicolumn{6}{|c|}{ Age group (years) } \\
\hline & 14 & 15 & 16 & 17 & 18 \\
\hline \multicolumn{6}{|l|}{ Soccer players } \\
\hline Endomorphic & $2,740,94 \pm *$ & $2,630,88 \pm^{*}$ & $2,580,75 \pm^{\star}$ & $2,540,72 \pm^{\star}$ & $2,440,72 \pm^{\star}$ \\
\hline Mesomorphic & $4,371,18 \pm^{*}$ & $4,381,10 \pm^{*}$ & $4,761,13 \pm^{*}$ & $4,761,10 \pm^{*}$ & $4,681,08 \pm^{\star}$ \\
\hline Ectomorphic & $3,481,15 \pm^{\mathrm{a}}$ & $3,281,05 \pm^{\mathrm{b}}$ & $3,010,99 \pm$ & $2,780,81 \pm$ & $2,910,85 \pm$ \\
\hline
\end{tabular}

Differences between soccerplayers ${ }^{\mathrm{a}}-14$ years vs. $15,16,17$ and 18 -year-old groups $\mathrm{p}<0.05$; $^{\mathrm{b}}-$ 15 years vs. 17-year-old groups $\mathrm{p}<0.05$.

\section{Discussion}

There is a large body of research which explores the anthropometrical characteristics and somatotypes among the top soccer players, as well as comparative research among the elite and non-elite players. The advantage of this study is that the anthropometrical measurings are conducted among the relatively great samples of young elite players in R. Macedonia from the best clubs of the first Macedonian league. The results of this research can serve as normative values for comparing the anthropometric and somatotypic data of young soccer players in our country and abroad.

The results of this study suggest that players at the age of 14 years, compared to all other age groups (15 to 18-year-olds), have lower body height and weight BMIindex. Based on this, it can be concluded that boys aged 14 and 15 did not complete their growth process. From 16 years onwards, the progression of height decreases, which suggests that these players gradually reach the height and weight. The average height of Macedonian adult soccer players (over 20 years) is $178 \mathrm{~cm}$, while the weight ranges from 72 to 77 kg. (Pluncevic-Gligoroska et al.,2014).

If we compare the results of our research with young players from other countries, we can conclude that the height and weight is similar to the young Croatian players (Jankovic et al., 1993), as well as Bulgaria, Portugal (Capela et al., 2003), and Brazil (Neto et al., 2007). Somewhat higher are the players from Switzerland (Tschopp et al., 2003), Norway (Helgerud et al., 2001), and Spain (Tschopp et al., 2003).

One of the greatest studies of the morphological and physical characteristics of young elite players was realized by Hulse (2010). The research was conducted on a sample of 2,252 respondents from U9 to U19. Comparing the results of our research with the results obtained in this study, it can be concluded that Macedonian players from the age of 14 to 16 are higher and heavier compared to English young players who are members of English professional soccer academies. On the other hand, English players at the ages of 17 and 18 are higher and heavier than Macedonian players.

Observations about the height and the weight of the players from different geographic regions show that players vary considerablyin that sense. Such differences can also be due to ethnic and cultural influences or they could be the result of a different style of soccer, with teams from different leagues preferring different types of players for certain positions (Bloomfield et al., 2003). However, with a general comparison between the players of the sports games and the general population, it can be concluded that soccer plaers are on average similar in height to the general population (Norton, Olds, 2001; Matkovic et al., 2003). In a certain number of studies it has been found that physical activity does not affect body measurements, growth-velocity, bone maturation (Beunen et al., 1992; Damsgaard et al., 2001; Malina, 1994) or adult height (Malina, 1994).

When it comes down to the somatotype, the main component of this sample of young soccer players is mesomorphic. It is logical that muscle structure is beneficial in performing various activities during the competition because those activities define the final result of the competition, for example, starting an opponent, acceleration, shooting and conducting a ball. Given the nature of the game, the expressed muscle development is more obvious on the lower part of the body than on the upper part. The group at the age of 14 showed the highest values of the ectomorphy component compared to all the other age groups. This is due to the fact that at this age players have less weight in relation 
to height. Similar results were obtained in the general population (Rosique, 1992) and among young players (Viviani et al., 1993).

\section{Conclusions}

The anthropometrical characteristics of the players can be an indication of the physical fitness of the athlete and therefore anthropometrical examination is an important segment of the athletes' physical (sports) examination. The youngest group of players (at the age of 14) showed significant differences in many parameters compared to all the other age groups. The obtained results can serve as normative anthropometric indicators for the regular sports medical examinations of young soccer players in our country. The data can also be used as a form for comparing the anthropometrical and somatotypical data of young players on a similar level from different countries.

\section{References}

American College of Sports Medicine Position Stand (ACSM) (2009), Nutrition and Athletic Performance, in Medicine and Science in Sports and Exercise, 41, pp. 709-731.

Bell, W. and Rhodes, G. (1975), The Morphological Characteristics of the Association Football Player, in British Journal of Sports Medicine, 9(4), pp. 196-200.

Beunen, G., Malina, R., Renson, R., Simons, J., Ostyn, M. and Lefevre, J. (1992), Physical Activityand Growth, Maturation and Performance: ALongitudinal Study, inMed.Sci. SportsExerc., 24, pp. 576-585.

Bloomfield, J., Polman, R. and O’Donoghue, P.G. (2003), Analysis of Elite Player Height and Body Mass from Four Major European Leagues, in Book of Abstracts from the WorldCongress on Science and Football5, GymnosEditorial Deportiva, p. 159.

Bojadzieva, S. B. (2015), Somatotype and Morphological Characteristics of Adolescents Aged 11 to 18 Years in the Republic of Macedonia, Unpublished doctoral dissertation, Ss. Cyril and Methodius University, Faculty of Medicine, Skopje, Macedonia.

Cacciari, E., Mazzanti, L., Tassinari, D., Bergamaschi, R., Magani, C., Zappulla, F., Nanni, G., Cobianchi, C. Ghini, T., Pini, R. and Tani, G. (1990), Effects of Sport (Football) on Growth: Auxological, Anthropometric and Hormonal Aspects, inEuropean Journal of Applied Physiology and OccupationalPhysiology, 61, pp. 149-158. Capela, C., Fragosol, I., Vieira, F., Charrua, C., Gomes-Pereira, J. and MilHomens, P. (2003), Physical Performance Testsin Young Soccer Playerswith Referenceto Maturation, in Book of Abstracts from the WorldCongressonScienceandFootball 5, Gymnos EditorialDeportiva, pp. 196-197.

Carter, J.E.L. and Heath, B.H. (1990), Somatotyping- Development and Applications, CambridgeUniversity Press, Cambridge.
Casais, L., Salgado, J., Lago, E., Pefias, C. (2013) Somatotype and Body Composition in Portuguese Youth Soccer Players, available at:

sigarra.up.pt/fadeup/publs_web.show_publ_file?pct_ gdoc_id $=2350$

Damsgaard, R., Bencke, J., Mathiesen, G., Petersen, J. and Muller J. (2001), Body Proportions, Body Composition and Pubertal Development of Children in Competitive Sports, in Scand. J. Med. Sci. Sports, 11, pp. 54-60.

Gil, S., Gil, J., Ruiz, F., Irazusta, A. and Irazusta, J. (2007), Physiological and Anthropometric Characteristics of Young Soccer Players According to their Playing Position: Relevance for the Selection Process, in J Strength Cond Res, 21 (2), pp. 438-445.

Helgerud, J., Engen, L.C., Wisloff, U. and Hoff, J. (2001), Aerobic Endurance Training Improves Soccer Performance, inMedicine and Science in Sports and Exercise, 33(11), pp. 1925-1931.

Heyward, V. and Wagner, D. R. (2004), Applied Body Composition Assessment, Human Kinetics, Champaigne IL.

Hulse, M. A. (2010), Physical Development and Progression to Professional Soccerof Elite Child and Adolescent Academy Players, Unpublished doctoral dissertation.

Jankovic, S., Heimer, N. and Matkovic, B.R. (1993), Physiological Profileof Prospective Soccer Players, in Science and Football II. Reilly, T., Clarys, J., and Stibbe, A. (Eds). E \& FN Spon, London, pp. 295-297.

Le Gall, F., Carling, C., Williams, M. and Reilly, T. (2010), Anthropometric and Fitness Characteristics of International, Professional and Amateur Male Graduate Soccer Players from an Elite Youth Academy, in Journal of Science and Medicine in Sport, 13, pp. 90-95.

Malina, R. (1994), Physical Activity and Training: Effects on Stature and the Adolescent Growth Spurt, inMed. Sci. Sports Exerc., 26, pp. 759-766.

Marković, G. and Bradić, A. (2008), Nogomet: Integralni kondicijski trening, Udruga Tjelesno vježbanje i zdravlje, Zagreb HR.

Matkovic, B.R.. Matkovic, B., Jankovic, S., Ruzic, L. and Leko, G. (2003), Morphological Characteristics of Elite Croatian Soccer Players According to the Team Position, inBook of Abstracts from the WorldCongressonScienceandFootball 5, Gymnos EditorialDeportiva, p. 172.

Meszaros, T., Mohacsi, J., Szabo, T. and Szmodis, I. (2000). Anthropometry and Competitive Sport in Hungary, inActa Biol Szeged,44 (1-4), pp. 189-192.

Neto, L.G.S., Nunes, C.G., Hespanhol, J.E. (2007). Fitness Profile of Under-15 Brazilian Soccer Players by Field Position, in Journal of Sports Science and Medicine, 6(Supplementum 10), p. 118.

Norton, K. \& Olds, T. (2001), Morphological Evolution of Athletes Over the20th Century: Causes and Consequences, in Sports Medicine, 31, pp. 763-783.

Pluncevic-Gligoroska, J., Todorovska, L., Dejanova, B., Maleska, V., Mancevska, S.\& Nikolic, S. (2014), Anthropometric Parameters in National Footballers in the Republic of Macedonia, in Prilozi, 35(2), pp. 147-154.

Reilly, T., Bangsbo, J. and Franks, A. (2010), 'Accuracy' - Detection of High Fatness-Co- Morbidities Compari- 
son, in Obesity Review, 11.

Rienzi, E., Drust, B., Reilly, T., Carter, J. E. and Martin, A. (2000), Investigation of Anthropometric and Work-Rate Profiles of Elite South American International Soccer Players, inJ Sports Med Phys Fitness, 40(2), pp. 162-169. Rogol, A., Roemmich, J. and Clark, P. (2002), Growth at Puberty, in J. Adol. Health, 31, pp. 192-200.

Rosique, J. (1992), Estudio transversal delcrecimiento en escolaresvizcaínos. Lavariación Antropométrica Como Componente de la Estructura Biológica de la Población, Doctoral thesis, University of the Basque Country, Leioa, Spain.

Tabara, Y., Moji, K., Tsunawake, N., Fukuda, R., Nakayama, M., Nakagaichi, M., Komine, T., Kusano, Y. and Aoyagi, K. (2006), Physique, Body Composition and Maxi- mum Oxygen Consumption of Selected Soceer Players of Kunimi High School, Japan, inJournal of Physiological Anthropology,25, pp. 291-297.

Tschopp, M., Held, T. and Marti, B. (2003), Four-Year Development of Physiological Factors of Junior Elite Soccer Players Aged Between 15-16 Years, in Book of Abstracts from the WorldCongress on Science and Football5, GymnosEditorial Deportiva, p. 307-308.

Van Lenthe, F., Kemper, H., Post, G., Twisk, J., Welten, D. and Snell, M. (1996), Biological Maturation and the Distribution of Subcutaneous Fat from Adolescence into Adulthood: The Amsterdam Growth and Health Study, in Int. J. Obes. Rel. Metab. Dis, 20, pp. 121-129.

Viviani F., Casagrande, G. and Toniutto, F. (1993), The Morphotype in a Group of Peripubertal Soccer Players, in J. Sports Med. Phys. Fitness, 33, pp. 178-183. 